\title{
ISSUES OF TRAINING ART TEACHERS IN THE CONTEXT OF EDUCATIONAL INNOVATIONS
}

\author{
QUESTÕES DA FORMAÇÃO DE PROFESSORES DE ARTE NO CONTEXTO DAS \\ INOVAÇÕES EDUCACIONAIS
}

\author{
TEMAS DE LA FORMACIÓN DE PROFESORES DE ARTE EN EL CONTEXTO DE \\ LAS INNOVACIONES EDUCATIVAS
}

\author{
Galyna PADALKA ${ }^{1}$ \\ Liudmyla PANKIV ${ }^{2}$ \\ Wang XIA ${ }^{3}$ \\ $\mathrm{Wu}$ QIRUI $^{4}$ \\ Zhang SHENGWEN ${ }^{5}$ \\ $\mathrm{Hu}^{\mathrm{TINGTING}}{ }^{6}$
}

\begin{abstract}
The purpose of the work is to determine the personal qualities of a music teacher that contribute to the effectiveness of his artistic and educational activities in modern conditions, the theoretical development of the essence, content, and component structure of the categories "artistic empathy", "style culture of performing musical works", "artistic and performing self-efficacy of the individual". Using the methods of questioning, testing, pedagogical observation, and analysis of lessons in the system of arts faculties of pedagogical universities of Ukraine and statistical processing of the materials obtained, the state of modern practice of professional training of future musicians is characterized. As a result of the study, it is argued that these qualities are among the dominant professional and personal qualities of a modern music teacher. The article confirms the prospects for forming these professional and personal qualities precisely in the process of special musical training of students.
\end{abstract}

KEYWORDS: Teacher. Education. Artistic empathy. Style culture. Performing self-efficacy.

RESUMO: $O$ objetivo do trabalho é determinar as qualidades pessoais de um professor de música que contribuem para a eficácia de suas atividades artísticas e educacionais nas condições modernas, o desenvolvimento teórico da essência, conteúdo e estrutura de

\footnotetext{
${ }^{1}$ Dragomanov National Pedagogical University (NPU), Kyiv - Ukraine. Professor of the Faculty of Art. Doctor of Pedagogic Sciences. ORCID: https://orcid.org/0000-0001-5110-9637. E-mail: ua.education.com.ua@gmail.com

${ }^{2}$ Dragomanov National Pedagogical University (NPU), Kyiv - Ukraine. Candidate of Pedagogic Sciences. PhD in Pedagogy. ORCID: https://orcid.org/0000-0002-6900-3336. E-mail: liudmylapankivv@gmail.com

${ }^{3}$ Dragomanov National Pedagogical University (NPU), Kyiv - Ukraine. Postgraduate of Faculty of Art. ORCID: https://orcid.org/0000-0003-4719-6541. E-mail: wangxiaaa1@gmail.com

${ }^{4}$ Dragomanov National Pedagogical University (NPU), Kyiv - Ukraine. Postgraduate of Faculty of Art. ORCID: https://orcid.org/0000-0001-7249-4378. E-mail: wuqiiruii@gmail.com

${ }^{5}$ Dragomanov National Pedagogical University (NPU), Kyiv - Ukraine. Postgraduate of Faculty of Art. ORCID: https://orcid.org/0000-0003-0030-0647. E-mail: zhangshengwennn@gmail.com

${ }^{6}$ Dragomanov National Pedagogical University (NPU), Kyiv - Ukraine. Postgraduate of Faculty of Art. ORCID: https://orcid.org/0000-0002-9236-8341. E-mail: hutingtingg1234@gmail.com
}

RPGE- Revista on line de Política e Gestão Educacional, Araraquara, v. 25, n. esp. 3, p. 1779-1794, Sep. 2021. e-ISSN: 1519-9029 
componentes das categorias "empatia artística", "cultura de estilo de execução de obras musicais", "autoeficácia artística e performática do indivíduo". Usando os métodos de questionamento, teste, observação pedagógica e análise das aulas no sistema das faculdades de artes das universidades pedagógicas da Ucrânia e processamento estatístico dos materiais obtidos, o estado da prática moderna de formação profissional de futuros músicos é caracterizado. Como resultado do estudo, argumenta-se que essas qualidades estão entre as qualidades profissionais e pessoais dominantes de um professor de música moderno. $O$ artigo confirma as perspectivas de formação dessas qualidades profissionais e pessoais justamente no processo de formação musical especial dos alunos.

PALAVRAS-CHAVE: Professor. Educação. Empatia artística. Cultura de estilo. Autoeficácia no desempenho.

RESUMEN: El propósito del trabajo es determinar las cualidades personales de un profesor de música que contribuyan a la efectividad de sus actividades artísticas y educativas en condiciones modernas, el desarrollo teórico de la esencia, contenido y estructura componente de las categorías "empatía artística", "cultura de estilo de la interpretación de obras musicales", "autoeficacia artística y escénica del individuo". Utilizando los métodos de cuestionamiento, prueba, observación pedagógica y análisis de lecciones en el sistema de facultades de artes de las universidades pedagógicas de Ucrania y el procesamiento estadístico de los materiales obtenidos, se caracteriza el estado de la práctica moderna de la formación profesional de los futuros músicos. Como resultado del estudio, se argumenta que estas cualidades se encuentran entre las cualidades profesionales y personales dominantes de un profesor de música moderno. El artículo confirma las perspectivas de formación de estas cualidades profesionales y personales precisamente en el proceso de formación musical especial de los estudiantes.

PALABRAS CLAVE: Docente. Educación. Empatía artística. Cultura de estilo. Autoeficacia escénica.

\section{Introduction}

The new requirements for the level of professional training of a music teacher are due to the growing humanistic role that he is called upon to play in modern conditions of the erosion of the aesthetic value guidelines of student youth. One of the drawbacks of training musical pedagogical personnel in modern higher education is the isolation of the special musical training of future music teachers from the needs of their future practical professional activities, not enough attention is paid to the formation of those professional qualities that would allow him to make the most of his personal resources in modern music and educational practice.

The need to make adjustments to the educational system made it possible to put forward the following hypothesis: among the most significant professional and personal qualities of a modern music teacher, necessary to achieve the effectiveness of musical and pedagogical 
activities in a modern school, should be attributed those such as artistic empathy; artistic and performing self-efficacy; style culture of performance of musical works.

In general, the analysis of scientific and methodological literature indicates that in the problems of professional training of a teacher of musical art, the issues of the formation of his artistic empathy, stylistic culture of music performance, and performing self-efficacy are practically absent. This is due to the prevalence of the "knowledge" paradigm in the musical teaching of students, with an underestimation of the developing potential of art, with the undeveloped conceptual and categorical apparatus of personal guidelines for the professional training of future teachers of musical art.

At the same time, it was revealed that the problems of teaching musical disciplines in the system of higher music education are considered quite widely. The technologies of musical and creative development of future music teachers have been investigated (WANG, 2016; STRATAN-ARTYSHKOVA, 2014; GUSACHENKO, 2018), several variants of diagnostics of professional competence, readiness of teachers for teaching music at school are proposed (PUHALSKY, 2018; STRATAN-ARTYSHKOVA, 2014; HUANG HANJIE, 2017) modern trends in the development of vocal, instrumental, conductor-choral training analyzed (DUBOVY, 2019; HUANG CHANGHAO, 2017; SUN, 2017). Of particular interest are studies in the field of art therapy methods, as well as training future teachers to use art therapy methods in music teaching (MALASHEVSKA, 2017; STROHAL, 2017); problems of introducing the polyartistic orientation of musical education (SHPITSA, 2016). General theoretical questions, such as the pedagogical potential of the educational environment (TSYUMAN, 2018), axiological aspects of education (DENSITY, 2004), the structuring of concepts (ZHUITIN, 2018; KHOMICH, 2016; DIKUN, 2017; LIANG, 2017) are also reflected in the modern scientific and methodological literature. However, when considering the results of these studies, it was found that when structuring categories, the necessary parameters of human activity are not always considered. So, considering the components of the readiness of future teachers of art disciplines to work with the choir, the author overlooks the motivational component of the concept of "readiness" (KHOMICH, 2016).

When solving special issues of musical education, scientists widely rely on praxeological (PROVOROVA, 2015), axiological (DENSITY, 2004; GAO RUOJUN, 2018; GUSACHENKO, 2018), communicative (ZAITSEVA, 2017a; 2017b) approaches as a foundation for solving problems of musical education. At the same time, a culturological approach, in which the leading figure in education is a creative individual, prone to self- 
determination, as well as a functionalist paradigm, which presupposes the practical orientation of student education in the higher education system, are not considered.

The lack of research in the field of modernization of music and pedagogical education determined the purpose of the article - to consider those professional and personal qualities of a music teacher that contribute to the achievement of the success of his educational activities in modern conditions, to propose an original development of the concepts of "artistic empathy", "performing self-efficiency", "style culture performance of music" in relation to the activities of a music teacher, to determine their essence, content and structure, to substantiate pedagogical functions.

\section{Materials and Methods}

To identify innovative trends in the higher education system, to develop the concepts of "artistic empathy of a teacher", "performing self-efficiency of a teacher", "style culture of performing music by a teacher" and their structuring in the process of scientific research, the methods of theoretical research were used - theoretical analysis, systematization.

Methods of scientific forecasting and modeling were also used to determine innovative progressive trends in the training of music teachers in the system of higher education. Modeling is viewed as a mental representation of a real system, which accordingly reflects the most significant characteristics of the original, becoming a source of new research information. At the same time, the predictive function of modeling, on which our research is based, makes it possible to foresee the prospective development of the revealed professional and personal qualities of a teacher as extremely important for musical and pedagogical activity.

The structuring of the identified categories is of great importance in the study - "artistic empathy of a music teacher", "style culture of performance of musical works of a teacher", "artistic and performing self-efficacy of a teacher", which makes it possible to present each of them in the form of integrity, combining individual specific characteristics of the studied phenomenon.

The characterization of the state of modern practice of professional training of future teachers was carried out based on the application of questionnaire methods, testing of graduate students, pedagogical observation, analysis of educational documentation, statistical processing of materials. A total of 280 graduate students from seven Ukrainian universities in different regions were surveyed. Statistical processing of the obtained materials made it possible to 
establish with sufficient probability that the studied qualities were formed at a high level in $9.5 \%$, at an average in $17.3 \%$, at a low in $73.2 \%$.

\section{Results}

The modernization of the training of music teachers in the system of higher education presupposes an emphasis on the formation of their professional and personal qualities. At the same time, we should note that traditionally the professional training of music teachers is considered primarily as musical and performing. It is believed that the development of the skills and abilities of music performance (singing, conducting, playing musical instruments etc.) is the most essential part of the professional development of a musician-teacher. It is assumed that the pedagogical component, mastering the methodology of teaching musical disciplines, plays a secondary, auxiliary role in teaching future music teachers. A survey of teachers of music disciplines, such as "Voice Production", "The Main Tool" of pedagogical universities shows that most of them believe that mastering the performing arts is a sufficient factor in the successful pedagogical work of students in the future. To the questions: "Do you pay attention to the methodological issues of voice production, achievement of artistic expressiveness in the performance of piano works?", "Do you consider it necessary to develop the pedagogical qualities of students in the process of teaching musical performing disciplines?" the following answers were received: "The main thing is to teach the student to perform music expressively and technically competently", "Pedagogical skills will come by themselves in the process of practical work with students", "Formation of pedagogical skills is a matter of concern for teachers of pedagogy" etc. At the same time, the fact is overlooked that graduates of the faculties of arts of pedagogical universities are unlikely to be able to realize themselves in practical work as musicians-performers. Disregard for teaching preparation puts graduates in a false position. As musicians-performers, due to objective and subjective reasons, they are unable to express themselves, and as teachers, they are not tuned in and prepared.

Unlike traditional approaches, it is proposed to focus efforts on such personality traits that would combine both professional pedagogical and professional artistic. These include such as the artistic empathy of the music teacher, the style culture of the teacher's performance of music, the artistic and performing self-efficacy of the music teacher. Let's consider them sequentially.

Artistic empathy is considered as the ability to adequately perceive and evaluate the figurative content of a work of art from the standpoint of subjective penetration into the 
emotional and semantic subtext of the experiences, reflections, attitudes towards the displayed phenomena embodied by the author. The artistic empathy of a music teacher is mediated, in addition, by the specifics of his professional activity, which involves the teacher's communication not only with art, but also with students. In addition, his own attitude to music is also predetermined by pedagogical tasks - to convey the artistic meaning of the work to students, to captivate them with the beauty of artistic images, to expand the stock of artistic impressions etc. Thus, the artistic empathy of a music teacher is interpreted in our study as a personal integrative education that presupposes the ability to empathize, subjectivize both the author's aesthetic experience and the value orientations of students' artistic perception. The functioning of artistic empathy, constituting the communicative dominant of the professional activity of a music teacher, determines its success, effectiveness, and efficiency.

It has been established that the structure of artistic empathy is among the main ones and includes motivational-incentive, cognitive-evaluating and presentational-creative components.

The motivational and incentive component of artistic empathy presupposes that the teacher has a stable desire to deeply delve into the emotional-figurative essence of the work, interest in the author's intention, the composer's creative intentions. Not superficial contemplation, but a truly thoughtful attitude to the content of music, its emotional expressiveness determines the direction of the teacher's attitude to mastering the art of music.

Artistic empathy is not manifested with a neutral perception of a musical work. Interest in experiencing the emotional implication of artistic images, in identifying their emotional and semantic fullness lies at the heart of the teacher's ability to adequately understand and experience the figurative essence of artistic creativity. The teacher-musician is also characterized by an interest in related arts - painting, theater, poetry. The lack of such interest indicates the lack of formation of artistic empathy.

The foregoing determines the pedagogical task - to maximally encourage the development of students' interest in learning artistic creativity, to activate their motivational aspirations for the broadest possible communication with art as a reflection of the inner world of a person.

The cognitive-evaluating component of the artistic empathy of a teacher of musical art indicates the existing stock of artistic impressions, the teacher has a certain experience of communication with art. It seems important for the teacher to have a wide range of knowledge of artistic works, actual musical material, as well as knowledge about art, about the work of composers. For a music teacher, it is extremely important to have a broad awareness of musical styles, artistic trends, the ability to understand the genre features of music. 
The cognitive-evaluating component of the artistic empathy of a teacher of musical art presupposes his ability both to objectively evaluate the artistic content of a work, means of expression, to analytically comprehend the figurative and artistic context of a work, and to a direct emotional-sensory reaction to a work. The immediacy of the emotional and artistic reaction must be supported by rational approaches in assessing the artistic merits of a work. Artistic empathy contributes to both the preservation of a vivid emotional response to a work of art, and the ability to rationalize the feelings that arise in the process of perceiving art images.

Artistic empathy primarily presupposes the brightness of the emotional response, the strength of the emotional response, and an orientation toward the immediacy of the impression. At the same time, the critical depth in the fabric of the work, the desire to understand the origins of one or another reaction, to intellectually comprehend the characteristic formative features of the work, not only do not hinder, but even intensify the experience, enhance the artistic and emotional impression. The reliance on analytical comprehension of the aesthetic value of art stimulates emotional experience, enhances the results of artistic and emotional deepening into the merger of artistic images. Reliance on analytical comprehension, the ability to intellectually comprehend the aesthetic value of art stimulates an emotional "entry" into the world of beauty, activates emotional empathy.

The presentational and creative component of artistic empathy means the ability of a person to intense, vivid empathy for the moods and emotions that make up the content of an artistic creation; to an active awareness of its form-making elements, which already at the stage of perception rises to the level of imaginary complicity with the author, and also certainly presupposes a tendency to express one's own attitude to art, a desire to share one's impressions with others.

Thus, on the one hand, artistic empathy contains a significant proportion of the awareness of the artist's creative impulses, so to speak, penetration into the author's creative laboratory as complicity, subconscious identification, awareness of the author's creative needs and their stimulants. On the other hand, artistic empathy presupposes the presence of desire, often also unconscious, to express one's own thoughts, one's own feelings and the nature of the experience of a work of art. An imaginary, almost always subconscious, creative dialogue made at an intuitive level with the author or performer of a work of art develops into a desire to share their own impressions, moods, sensations of the artistic essence of the work of art.

In general, the structure of the teacher's artistic empathy includes components that indicate the presence of stable interest, the teacher's desire to master the deep essence of the content of the musical image, to understand its emotional implication, the desire to establish 
emotional and artistic contact with students. Artistic empathy also presupposes the presence of artistic experience, a certain stock of artistic impressions, the ability to understand artistic trends, styles, and genre features. The artistic and empathic attitude towards music and its teaching is also expressed in the teacher's ability to creatively experience a literary text at the level of imaginary complicity with the author, in the ability to enter a creative dialogue with him, and also to share his impressions with students.

These components are inextricably linked, holistically embracing the concept of artistic empathy of a music teacher. So, for example, the intensity of a person's sensorial reaction to the aesthetic merits of a work depends on the formation of the motivational component of artistic empathy. The reliability of the rational-analytical assessment of the artistic quality of a work evokes a desire for its re-perception. The creative dialogue with the author amplify the intensity of empathy for artistic images.

One of the most essential tasks of the school music teacher is to instill in students' high artistic tastes, to develop their ability to fully perceive art, understand and experience artistic images. The style culture of the teacher plays an essential role in this. By the style culture of the performance of musical works we mean an integrated personal quality that expresses the ability to reproduce the system of figurative and musical-formative thinking of the composer in unity with the expression of an individual's own attitude to the content of music in the process of interpreting artistic images. The content of the performing-style culture of the musicianteacher is complemented by the readiness to convey the content of artistic images in the entirety of the composer's style to young listeners, to captivate them with music. In general, the style culture of performing musical works is the most important indicator of the teacher's professionalism.

The structure of the style culture of a music teacher includes motivational-incentive, cognitive, evaluative-emotional, initiative-creative and communicative-pedagogical components, which in systemic interaction express the teacher's desire for deep knowledge of the composer's style and the specifics of the style perception of music by students.

The motivational and incentive component of the style culture of performing musical works implies that the teacher has a desire for a deep knowledge of the author's style, a desire to penetrate the sphere of his figurative thinking and the peculiarities of form creation to an expressive and style-appropriate performance of his works.

The role of motivation as an activator of activity has been convincingly proven by psychological research. S.D. Smirnov, understanding the systemic unity of stimulating factors by motivation (SMIRNOV, 2001). Emphasizes that developed motivation is one of the most 
important determinants of human behavior. Based on this idea, we note that the motivational and incentive component of the style culture of the teacher-musician's performance also provides for the formation of the attitude, the developed need for performing music in front of young listeners, the desire, through their own performing abilities, to form high guidelines for the perception and assessment of art in students style guidelines. Thus, the motive for achieving a style of appropriate performance is an important professional characteristic of a teacher, determines the success of his musical and performing formation and professional and pedagogical development.

The cognitive component orients the teacher-performer to enrich knowledge regarding various stylistic spheres of musical culture and the practical mastering of music on a stylistic basis. The teacher needs to deeply understand and feel the originality of the author's style, the national basis, the historical conditioning, the genre specificity of his style thinking. The system of his musical-theoretical and musical-performing knowledge includes a wide range of information about the creative achievements of all kinds of composing schools and artistic directions, means of musical expression. Stratan-Artyshkova T.B. in her monograph emphasizes that holistic ideas about the stylistic basis of musical art, due to the peculiarities of the historical era, acquire a special significance in the preparation of a musician (STRATANARTYSHKOVA, 2014). Sun (2017) focuses on the need to achieve a synthesis of theoretical concepts regarding the musical style and their practical reflection in the performing process. As our research has shown, the cognitive component of the style culture of the performance of music by a teacher should also be supplemented with psychological knowledge about the specifics of the perception of music by different age groups of students, as well as methodological erudition in the field of artistic and pedagogical interpretation of music.

The evaluative-emotional component testifies to the performer's ability to objectively evaluate the content of musical images created by the composer based on their deep subjective experience. Concentrating on the decoding of the author's intention, the performer at the same time must reveal in the interpretation his own understanding, his own assessment, not an indifferent, but an emotionally inspired attitude to music. Otherwise, his performance risks turning into a formal, dry, faceless process of reflecting other people's artistic intentions.

Expressing a vivid emotional attitude towards the music being performed is especially important for a performer teacher. The neutral, indifferent reflection of musical images is unacceptable anywhere, since music is an art that, more than other types of art, has the ability to convey human emotions. In the process of working with the student audience, the importance of the emotionality of the performance increases significantly. Scientists-educators emphasize 
that students in the age range from 7 to 16 years old are characterized by increased emotional activity, sometimes even emotional tension is inherent in them, a greater brightness of experiences compared to adults. The ease of the emergence of emotions, the tendency to change moods cannot but influence the nature of the musical perception of students. A teacher who performs music cannot but pay attention to these circumstances, his emotional and evaluative attitude to music is the factor of attraction to art, that regulator that allows the teacher to captivate children with his own performance of musical style nuances.

The initiative-creative component of the style culture of performance means the teacher's ability to identify a creative approach to the interpretive interpretation of artistic images, while the teacher-performer strives for the most complete transfer of the author's content. The performer of musical works always faces stylistic problems of interpretation because the correlation between the stylistic specifics of a work and its interpretation cannot be solved solely at the general aesthetic level. It is necessary to consider the psychological laws, patterns of perception of music by listeners, take into account their artistic potential, factors of personal mastery of musical images by the performer. At one time, G.G. Neuhaus, an outstanding performer and teacher, successfully emphasized the paradox of the performing arts, inviting students to highlight accents in the phrase: "I play Chopin" by stressing the first or third word.

At the same time, attention should be paid to the complexity of the interpretive reading of a work of art. The interaction of the performer with the composer contains many shades that cannot be put into a simple scheme: "Both the comprehension of the style and the reflection of one's own emotional attitude to the author's work." The interpreter's creative approach contains many psychological nuances, shades of correlating his understanding and feeling of musical images and their composer's intention.

It should also be borne in mind that the performer teacher carries out not only an imaginary dialogue with the composer, but also communicates with the students, trying to convey to them the musical creation in all the fullness of the colors of both the composer's and his own sense of art. Therefore, the interpretation of music intended for students to listen to, presupposes an intense creative search on the part of the teacher-performer. The creation of an interpretation that is accessible, understandable, interesting, and exciting for schoolchildren in no way implies a simplified interpretation of music. A teacher cannot and should not be led by the immature aesthetic preferences of schoolchildren. In this way, a rather complex creative task arises before the teacher, which cannot be completed without creative inspiration, initiative, originality of artistic and figurative thinking. The creative coloring of the interpretive 
process is an indispensable companion of the teacher's performance of music. The dialogue between the performer-teacher and the composer, aimed at young listeners, acquires special creative characteristics associated with the need to consider the listening abilities of children, the peculiarities of their musical readiness.

Achieving creative interaction with listeners is based on the formation of the teacher's motivation for a stylistically verified interpretation of music, which would contribute to expanding the horizons of understanding and experience of art by students. In turn, the pedagogical and artistic motivation of the performer teacher should be correlated with the possibility of creating a holistic interpretative concept for him, where the interpretation of the emotional-figurative meaning would be based on the understanding of the stylistic basis of the work and would also correlate with the capabilities of the audience. And finally, a special importance in the performing style culture of the teacher prioritizes his ability to choose artistic and performing techniques that would contribute to the establishment of creative contact with students-listeners. The advancement of these requirements is based on the laws of the artistic influence of music, which were deeply substantiated in the works of Wang (2016), A.V. Zaitseva (2017), Huang Changhao (2017)

The modern music teacher must be responsible for continuous improvement in his profession. Confidence in his ability to captivate children with music, the ability to effectively use his own musical and performing resources, the effectiveness in the application of methods and techniques of artistic interaction with students are the characteristic features of his professional activity. Self-efficacy reflects these qualities as the ability to project one's own behavior, to consciously change oneself in accordance with one's own ideas.

The motivational and cognitive component of artistic and performing self-efficacy expresses the ability to solve problems in an optimal way, expresses the teacher's desire to reach the highest level of realizing his own performing abilities, to achieve success in performing activities. This aspiration is mediated by a rational awareness of the usefulness of musical performance in the teacher's professional work, recognition of the role of one's own "I" in the process of performance, the effectiveness of one's own artistic and performing efforts in the musical development of children. The cognitive context of this component assumes the development of thinking, the activity of memory and cognitive processes, thereby stimulating the motivational factors for achieving success. Thus, the motivational and cognitive component characterizes the firmness of the teacher's intentions in creating an optimal, artistically verified performing interpretation of music, a conscious attitude towards artistic performance efficiency 
as a powerful means of influencing the musical and aesthetic development of students, the conviction in the presence of the necessary knowledge, skills.

The emotional-volitional component acts as a determinant of the ability to positively perceive the course and results of the process of interpreting music, hedonistic experience of the performed musical work, conviction in one's own abilities to realize the emotional and educational influence of artistic performance.

The performing presentation of music in the children's auditorium by a teacher with a high level of self-efficacy is devoid of negative emotions of fear, uncertainty, dissatisfaction and is perceived as an act of successful artistic contact with children. At the same time, volitional efforts acquire a positive emotional orientation, express firm confidence in the possibilities of artistic influence on the musical consciousness of students, in the ability to captivate them with music in their own performance. Emotional belief in one's own performing and musical-pedagogical capabilities complements the motivational and cognitive characteristics of the artistic and performing self-efficacy of a music teacher.

The control and assessment component assume the teacher's ability to assess their own interpretive and artistic abilities, as well as the listeners' impressions of their artistic and performing skills. The ability of objective self-esteem in musical performance, in particular, performances in front of young listeners, directs musical communication with students, helps to find the necessary line of pedagogical behavior, and acts as a correlate of the development of artistic and performing self-efficacy. Artistic and performing self-efficiency is determined by the ability to evaluate the results of one's own musical-interpretive and pedagogical activity, without underestimating one's own achievements. An optimistic self-assessment of musical and performing competence, pedagogical behavior, creative possibilities and experience of interacting with student youth inspires productive activity and new achievements. The positive opinion that the teacher makes about himself and the ability to see his best features through the eyes of others stimulates the emergence of a sense of self-respect, self-sufficiency, awareness of the value of his activities, usefulness, and his own success. And on the contrary, low selfesteem causes fear, uncertainty in their performing skills, in their own possibilities of artistic influence on students, which ultimately reduces the level of self-efficacy, hinders the success of the teacher's musical and pedagogical activity.

The creatively activating component testifies to the teacher's ability to apply new, original approaches to the performance of musical works, not only little-known ones, but also those that have broad traditions of performance. The readiness to introduce innovative approaches to the organization of listening to music by schoolchildren, the ability to apply a 
creative strategy in the artistic and pedagogically thoughtful presentation of music characterizes the creative and interpretive component of self-efficacy. Belief in one's own creative abilities, conviction in the effectiveness of one's own creative actions generates creative energy, directs it towards achieving high goals - to make masterpieces of musical art accessible to every student.

The communicative and regulatory component of the artistic and performing selfefficacy of a music teacher is focused on the creation and implementation of a performing interpretation of a musical work in accordance with the situation of its perception by others, in particular, designed for the perception of students of a certain age. Public speaking for a selfeffective performing teacher contains hedonistic value. Interaction with students during the performance of music (the teacher performs, children listen) brings him a positive charge of emotionality, contributes to the achievement of aesthetic satisfaction, obtaining vivid artistic impressions. The self-efficacy of the teacher, who speaks to the student audience, is also manifested in the ability to target children's reactions to music, if necessary, to adjust their own performance accordingly (naturally, within the framework of good taste).

These components as a whole express the desire of the performer teacher to solve problems in an optimal way, to achieve the highest degree of realization of his own performing abilities in the audience of young listeners, the absence of negative emotions in public performance; presuppose the teacher's ability to objectively assess his own performing qualities, the ability to see the best features of his performance "through the eyes" of others; testify to the teacher's ability to apply new, original approaches to the performance of musical compositions and the organization of students' listening to music.

\section{Discussion}

The considered issues acquire a polemical acuteness in connection with the identification of new, previously not developed categories - "artistic empathy of a music teacher", "style culture of performing musical works of a teacher", "artistic and performing self-efficacy of a teacher". The structuring of these concepts, which implies the interconnection of artistic and pedagogical components, also differs in novelty.

The appeal to these categories is motivated by the assertion that such professional and personal qualities of a teacher as artistic empathy, stylistic culture of performing musical works, artistic and performing self-efficacy are dominant in modern conditions of musical and pedagogical activity. It is argued that these qualities help to overcome the most common 
difficulties and shortcomings of the practical work of teachers with modern schoolchildren, in particular, with the inability to establish artistic contact with students, the manifestation of uncertainty in the choice of optimal pedagogical technologies, confusion at the time of the performance presentation of music in the classroom of schoolchildren; with a fairly low level of musical and performing training of students.

The article focuses on the opinion about the enduring value of the "live" sound of music in the modern artistic and educational process, about the impossibility of completely replacing it with sound-reproducing equipment.

The role of the pedagogical orientation of musical education of future music teachers is especially emphasized, despite the traditional limitation of their performing training exclusively to the tasks of artistic development.

\section{Conclusions}

In conclusion, let us emphasize the importance of the findings for the development of scientific ideas about the theory and methodology of musical education in the higher education system. The development of the categories "artistic empathy of a music teacher", "style culture of performance of musical works of a teacher", "artistic and performing self-efficacy of a teacher" proposed in the article reveals guidelines for improving the teaching of musical performance disciplines in modern conditions, creates a theoretical basis for substantiating and implementing approaches that take into account the need, first of all, for the personal development of students in performing classes. Focusing on these categories helps to overcome the widespread practice of orientation of training, in which the teacher's efforts are focused on transferring to students the experience of mastering certain methods of vocal performance, on mastering the techniques of playing the piano, violin, button accordion, or the formation of conducting and choral skills. Contrary to the existing practice, in which the main criterion for the effectiveness of musical training of future teachers is their knowledge and performing skills, the material proposed in the article draws attention to the need to develop a system for assessing students' achievements in the art of music, considering their personal development, in particular, the ability to empathy, the formation of the style culture of the performance of musical works, the development of an artistic performer of self-efficacy.

The conclusions obtained acquire practical value for modernizing the training of pedagogical personnel in modern conditions and can be used in the process of writing curricula, teaching aids, improving the practice of special education for future music teachers. 


\section{REFERENCES}

DENSITY, H.A. Axiological aspects of domestic education as a factor in the formation of professional and value orientations of the future teacher. Kaluga. 2004.

DIKUN, I. The content and structural characteristics of future Music teachers' creative activity experience. Intellectual Archive, 1(6), 51-58. Toronto (Canada): Shiny Word.Corp. 2017.

DUBOVY, Z.S. Specifics of distance learning of future music teachers. Methodical practice: a journal for teaching and learning. Belgrade: Faculty of Teacher Education in Vranje and "School Book" DOO in Belgrade, 1,125-129. 2019.

GAO RUOJUN. Forming the ability to self-control - an important factor 0f improving the piano teaching and performance of future music teachers. Intellectual Archive, 3(7), 116127. 2018. Toronto: ShinyWord.Corp. (Canada).

GUSACHENKO, O. Valorificarea strategiilor inovaționale de dezvoltare a învățământului artistic contemporan", conferinţă ştiinţifico-practică internaţională. Bălți, 116-122. 2018.

HUANG CHANGHAO. Current trends in the development of vocal education future music teachers. 2017.

HUANG HANJIE. Musical-scenic partnership in the training of music teachers. The modern system of art education: formation, development, innovation. Astana: KazNUI. 2017.

KHOMICH, I.M. The structure of the readiness of future teachers of art disciplines to work with the choir. Yearbook of the Pedagogical Faculty in Vranje. Cataloging in the publication of the National Library of Serbia, Belgrade. 2016.

LIANG, H. A component structure of readiness of future music masters is to vocally-choral work with application of project technologies. KELM Scientific issue of knowledge, education, law and management. Wydawca: Fundacja «Oświata i Nauka Bez Granic PRO FUTURO», 2(18), 84-93. Łódź. 2017.

MALASHEVSKA, I. The Main Principles of Music Education of Preschool and Junior School Age Children during Music Therapy Training. Znajduje się wmonografii pt. Dobro i zło w wychowaniu dziecka. Kraków, 27-31. 2017.

PROVOROVA, E.M. Preparation of the future music teacher for lesson design: praxeological approach. Scientific journal "ScienceRise" Pedagogical education, 10/5 (15), 49-53. 2015.

PUHALSKY, T.D. Diagnosis and analysis of the levels of professional competence of future teachers by means of conducting and choral disciplines. Proceedings from international scientific conference: advances of science. Czech Republic, Karlovy Vary. 2018.

SHPITSA, R.I. Innovations in the integrated Music lesson: educational call of modern realias in comprehensive schools. Science and practice: Collection of scientific articles. Thorpe 
Bowker. Melbourne, Australia, 307-310. 2016. Available:

http://enpuir.npu.edu.ua/handle/123456789/11880

SMIRNOV, S.D. Pedagogy and psychology of higher education: from activity to personality: textbook. manual for students of higher educational institutions. Moscow: Publishing Center “Academy”. 2001.

STRATAN-ARTYSHKOVA, T.B. Creative and performing training of future music teachers. Monograph. Kirovograd: KSPU named after V. Vinnichenko. 2014.

STROHAL, T. YR. Methodical basis of using innovative art therapeutic technologies in the process of teenagers' emotional and aesthetic experience formation. Intellectual Archive, 1 (6), 89-101. Toronto. 2010.

SUN, P. Semiotic art interpretation skill in music teacher's training process (pedagogical principles). The Scientific Heritage, 15, 41-47. Budapest, Hungary. 2017.

TSYUMAN, T.P. Code of safe educational environment. Kyiv: Ukrainian Foundation for the Welfare of Children. 2018.

WANG, K. Formation of heuristic thinking of future teachers of music art and its results. EUROPEAN HUMANITIES STUDIES: europejskie stydia humanistyczne: Psychological, pedagogical and organizational conditions for the introduction of European standards of higher education: State and Society. Slupsk, Poland, 1, 51-61. 2016.

ZAITSEVA, A.V. Artistic and communicative culture of the future teacher of music: theory, methodology, methodological aspects: monograph. Kyiv: M.P. Drahomanov National Pedagogical University. 2017a.

ZAITSEVA, A.V. Methodical recommendations "Pedagogical guidance of the process of formation of artistic and communicative culture of the future music teacher". Kyiv: M.P. Drahomanov National Pedagogical University. 2017b.

ZHUITIN, L. Component structure of formation of musical and aesthetic taste of teenagers. Science and Education a New Dimension. Pedagogy and Psychology, VI (68), 51-55. 2018.

\section{How to reference this article}

PADALKA, G.; PANKIV, L.; XIA, W.; QIRUI, W.; SHENGWEN, Z.; TINGTING, H. Issues of training art teachers in the context of educational innovations. Revista on line de Política e Gestão Educacional, Araraquara, v. 25, n. esp. 3, p. 1779-1794, Sep. 2021. e-ISSN: 15199029. DOI: https://doi.org/10.22633/rpge.v25iesp.3.15592

Submitted: $20 / 03 / 2021$

Required revisions: 05/06/2021

Approved: $12 / 07 / 2021$

Published: 01/08/2021 